RESEARCH NOTES

\title{
Project Office as a Promising Management Tool in the Financial Market
}

\section{Oficina de proyectos como herramienta de gestión prometedora en el mercado financiero}

\author{
Andrey Petrovich Garnov \\ Plekhanov Russian University of Economics, Stremyanny lane, 36, Moscow, 117997, Russian \\ Federation \\ ORCID: 0000-0003-1435-8698
}

Andrey Yuryevich Belyaninov

Plekhanov Russian University of Economics, Stremyanny lane, 36, Moscow, 117997, Russian Federation

ORCID: 0000-0002-0323-0907

\section{Natalia Alekseevna Prodanova}

Plekhanov Russian University of Economics, Stremyanny lane, 36, Moscow, 117997, Russian Federation

ORCID: orcid.org/0000-0001-5140-2702

\section{Denis Grigorevich Perepelitsa}

Plekhanov Russian University of Economics, Stremyanny lane, 36, Moscow, 117997, Russian Federation

ORCID: 0000-0003-1678-1342

\section{Bahrom Asrorovich Tursunov}

Plekhanov Russian University of Economics, Stremyanny lane, 36, Moscow, 117997, Russian Federation

ORCID: 0000-0002-0037-0840

\section{Kosnikov Sergey Nikolaevich}

Kuban State Agrarin University named after I.T. Trubilin,350044, Krasnodar Krai, Krasnodar city,

Kalinina St. 13, Russian Federation

ORCID:0000-0002-2918-8209

Received 09-08-20 Revised 10-10-20

\section{*Correspondence}

Email: profgarnov@yandex.ru
Accepted 12-12-20 On line 03-12-21

Citation:

Andrey Petrovich Garnov, Andrey Yuryevich Belyaninov, Natalia Alekseevna Prodanova, Denis Grigorevich Perepelitsa, Bahrom Asrorovich Tursunov, Kosnikov Sergey Nikolaevich. (2021). Project Office as a Promising Management Tool in the Financial Market. Propósitos y Representaciones, 9 (SPE3), e1136. Doi: http://dx.doi.org/10.20511/pyr2021.v9nSPE3.1136 


\begin{abstract}
In the context of a dynamic external environment and continuously emerging global challenges, one of the most important issues for any corporation is its effective functioning and development in the long term. The current state of the markets is characterized by constantly changing external factors that have a significant impact on the position of the corporation in the market. Obviously, in order to carry out their activities, corporations must adapt to the impact of environmental factors by improving the structure of the organization and the quality of management. At the same time, the best results are achieved by those corporations that are able to effectively organize their activities for a long-term (strategic) period. To organize effective strategic management and the formation mechanism of the implementation of development strategies of the Corporation are encouraged to use project-based approach involving activities by initiating, designing, implementing and maintaining projects and programs of the Corporation, provide design controls created by attracting specialists with the necessary competencies in this area. Justifying the expediency of using the project approach, the article describes some general approaches to the organization of such structures, considers their tasks and functions. For organizations (corporations) that aim to achieve long-term success, it is absolutely necessary to find and master methods of managing their own development that provide them with competitive advantages and ensure faster growth rates in the field of activity or industry of the economy. The article is aimed at specialists interested in the management problems of modern socio-economic systems.
\end{abstract}

Keywords: corporate management, financial mechanism, mechanism for implementing the corporation's development strategy, plan for implementing the corporation's development strategy, project activity, project committee, project office, project approach

\title{
Resumen
}

En el contexto de un entorno externo dinámico y desafíos globales que surgen continuamente, uno de los temas más importantes para cualquier corporación es su funcionamiento efectivo y su desarrollo a largo plazo. El estado actual de los mercados se caracteriza por factores externos en constante cambio que tienen un impacto significativo en la posición de la corporación en el mercado. Evidentemente, para el desarrollo de sus actividades, las corporaciones deben adaptarse al impacto de los factores ambientales mejorando la estructura de la organización y la calidad de la gestión. Al mismo tiempo, los mejores resultados se obtienen en aquellas empresas que pueden organizar eficazmente sus actividades durante un período (estratégico) a largo plazo. Para organizar una gestión estratégica eficaz y el mecanismo de formación de la implementación de las estrategias de desarrollo de la Corporación se alienta a utilizar un enfoque basado en proyectos que involucre actividades al iniciar, diseñar, implementar y mantener proyectos y programas de la Corporación, brindar controles de diseño creados por la atracción de especialistas con las competencias necesarias en esta área. Justificando la conveniencia de utilizar el enfoque de proyecto, el artículo describe algunos enfoques generales para la organización de tales estructuras, considera sus tareas y funciones. Para las organizaciones (corporaciones) que pretenden alcanzar el éxito a largo plazo, es absolutamente necesario encontrar y dominar métodos de gestión de su propio desarrollo que les proporcionen ventajas competitivas y aseguren tasas de crecimiento más rápidas en el campo de actividad o industria de la economía. El artículo está dirigido a especialistas interesados en los problemas de gestión de los sistemas socioeconómicos modernos.

Palabras clave: gestión corporativa, mecanismo financiero, mecanismo para implementar la estrategia de desarrollo de la corporación, plan para implementar la estrategia de desarrollo de la corporación, actividad de proyecto, comité de proyecto, oficina de proyecto, enfoque de proyecto.

\section{Introduction}

In the conditions of constantly occurring changes in the competitive environment, accelerated scientific and technological progress, current planning is clearly not enough to ensure the sustainable development of the corporation for a long period. This makes it necessary to 
implement a strategic approach to corporate governance based on a set of principles that ensure the achievement of long-term goals. The main of these principles are: complexity, continuity and flexibility, information insufficiency, uncertainty, orientation to the future, time synchronization. These principles are implemented in turn in the system of strategic planning documents of the corporation. One of the most important documents in this system is the corporation's development strategy, which sets priorities, strategic goals and objectives for a long period (6 or more years), as well as determines the mechanism for implementing the corporation's strategy. At the same time, the mechanism is understood as a set of measures, rules, methods and means aimed at achieving strategic goals. Currently, almost all corporations develop animprovement strategy, but not all of them have developed a mechanism for its implementation (Nalchatji, 2015). The current practice of strategic planning

In most Russian companies, it offers as the most common mechanism for implementing the corporation's development strategy the development of a plan for implementing the corporation's development strategy (hereinafter referred to as the strategy implementation plan). It should be noted that the implementation plan is used both in the practice of corporate strategic planning and in state strategic planning, regulated by Federal Law No. 172 of 28.06.2014 "On Strategic Planning in the Russian Federation". According to this law, the strategy implementation plan is defined as a strategic planning document containing a list of measures that ensure the gradual achievement of the goals defined by the strategy, indicating the timing of implementation, volumes and sources of funding, as well as indicators of current and expected results of their implementation.

It should be noted that the development of a strategy implementation plan requires a sufficiently detailed definition of the necessary measures and resources for their implementation. Therefore, there is a high risk of inaccuracy of input used in the selection of these measures substantially complicates their definition for a long-term period equal to the period of the strategy development. This circumstance, therefore, makes it almost impossible to form an effective mechanism for implementing the strategy on the basis of this plan. In this regard, it is obvious that there is a need to use a different approach, which on the one hand would ensure the relationship of current activities with the goals of long - term or strategic development, and on the other-would allow to identify such measures that would ensure the achievement of strategic goals in the most effective way. One of the ways that, in particular, can be used in this case is the project approach, based on the use of project activity tools, which generally ensures the initiation, preparation, implementation and completion of relevant programs (plans) based on project management. Such management involves, in particular, the use of network structure of organization management (project planning process) with the involvement of professional competence of specialists and determining in the management of specific measures for achievement of goals gradually and consistently. Essentially, this implies the need to split long term objectives (movement towards the goal) set by the development strategy in the medium stages with definition of all necessary parameters of the initial step in the priority development program of the corporation for the medium term. The distinctive features of such a program are complexity, focus on achieving practical results, resource availability, time certainty, and validity.

\section{Research methods}

The main research tools used in this work are system analysis. Methods of empirical research, principles of formal logic, synthesis and analysis of works of Russian and foreign scientists are used to study theoretical and practical material.

\section{Results of the research}

What is the degree of implementation of project management software in organizations? management. (PMI)

To begin with, only $58 \%$ of companies fully understand the value of project

- $\quad 93 \%$ of organizations report using standardized project management practices. 
- $68 \%$ - more than 2/3-of organizations that participated in the annual PMI survey said they engaged third-party or contract project managers (PMI) in 2018.

- File sharing, time tracking, email integration, Gantt charts, and budget management are the five most popular and sought-after features of project management software. (Capterra)

- According to the Wellington survey, only $22 \%$ of companies use project management software. Coincidentally, 55\% of organizations do not have access to real-time KPIs. As a result, $50 \%$ of respondents said they spend between one and several days manually compiling project reports, highlighting the huge productivity gains from using project management software. (Wellingtone)

- Between 2017 and 2018, the percentage of organizations using spreadsheets to manage agile projects decreased from $74 \%$ to $67 \%$. Instead, they switched to specialized project management tools. (VersionOne)

- $\quad 77 \%$ of high-performance projects are executed using project management software. Despite this, the level of implementation of project management software remains low ( $22 \%$ - see above). $66 \%$ of project managers say they will use project management software more widely if they have adequate support from their organization. (Hive)

- $\quad 56 \%$ of companies used only one project management system. On average, organizations spend $\$ 861$ per month on project management software. The majority - 54\% - use local project management software, although this is changing rapidly. (Capterra)

In order to prepare and implement the corporation's development program for the mediumterm period, the organization must ensure the organization of project activities, which begins with the establishment of a special management body - the project office (committee), which is directly subordinate to the highest management body of the corporation. The basic documents for the organization of the project office (committee) are the regulations on the Project Office (committee) and its personal composition, approved in accordance with the procedure determined by the corporation's management body. At the same time, the first document establishes the goals, tasks, powers and organization of the Project Office (committee), and the second one defines the composition of specific specialists (experts, consultants, designers, etc.) involved in its work. The main goal of the project office (committee)is, therefore, to form, ensure the implementation and timely updating of the corporation's development program for the medium term. Taking into account the special (personalized) procedure for forming the composition of the project office (committee), it is obvious that the main advantage of such a management body is its professional and thematic orientation, which allows the most effective interaction between specialists in various fields and use them to choose the most effective measures for implementing the corporation's development strategy. In addition, the subordination of the project office (committee) directly to the highest management body of the corporation allows you to speed up the preparation and adoption of necessary management decisions by eliminating formal procedures that regulate the procedure for passing and approving measures and documents (Persod, 2014), especially necessary and important in the case of using a vertically integrated management organization scheme.

As part of the process of forming and implementing the corporation's target development program for the medium-term period, the activities of the Project Office (committee) should be regulated by the relevant regulations approved in accordance with the procedure adopted by the corporation, and include such sections as tasks, powers, and functions.

In general, the Project Office (committee) should solve the following main tasks (Gnedykh, 2015; http/ / wwwpetersburgsmartcity. Ru; http: //forpm.ru; Titov, 2014):

1. Conduct an ongoing analysis of the experience and best practices of leading, high-tech Russian and foreign corporations, as well as trends in the scientific and technical development of the industry.

2. Form project proposals on the main directions of the corporation's strategic development.

3. Select projects for the formation of a target program for the development of the corporation in the medium term. 
4. Develop a project passport for each project included in the target program of mediumterm development.

5. Provide a unified procedure for the development of the project, including the forms of documents and the content of sections.

6. Identify those responsible for the implementation of a specific project (form working groups in the following areas).

7. Conduct regular monitoring of the project implementation by reference points (project milestones).

8. Make a decision on early completion of the project (if necessary).

9. Review and evaluate the project implementation report upon completion.

To solve the tasks set, the project office (committee) should perform the following functions in the corporation (Valiev, 2011; http://www.projectimo.ru):

- analytical function-involves conducting a continuous study of best practices, trends in the development of the industry and incoming project proposals;

- coordinating function-coordinates the activities of departments for the preparation of project proposals and project implementation;

- consulting function-advises project managers and executors on project development and organization of work on projects;

- control function-monitors the implementation of planned activities, the achievement of planned indicators and the results of project implementation;

- methodological function-development of methodological materials for the formation of a unified project system in the corporation, including unified templates of project documents, unified templates of reports, regulations for the preparation, implementation and completion of the project, etc.

In order for the project office (committee) was able to effectively perform the tasks and functions assigned to it, it is advisable to give it the following powers (Valiev, 2011): corporation.

1. Request and receive internal and external information available to the divisions of the

2. Appoint or submit proposals to management on the appointment of project managers and the composition of the project office.

3. Provide methodological support and assistance to the project office in planning work on the project.

4. Make decisions (submit proposals to the management) on the inclusion of the project in the comprehensive development program for the medium-term period.

5. Request and receive reports on the implementation of projects at checkpoints and at the end of the project.

6. Involve external experts and consultants to optimize project activities, as well as to consult in a specific area of knowledge.

7. Provide the necessary information to the corporation's supreme executive body and the Board of Directors (Strategy Committee under the Board of Directors) on the progress of project implementation and the process of forming the corporation's target development program for the medium-term period.

Therefore, the project office (committee) it becomes a kind of competence center for the preparation and implementation of projects and activities aimed at achieving strategic goals. At the same time, the project office (committee) should have its own internal structure and regulatory and methodological support. When forming a project office (committee) in the corporation, the regulation "On the project office for the implementation of the strategy"is developed. The regulation contains information about the goals and objectives, functions and powers of the office. In the position approved by the membership, organizational structure and organization of the project office (Persod, 2014) and (http/ / wwwpetersburgsmartcity. ru).

In the practice part of the project management office (Committee) may include the head of the project office, Deputy head of project office, Executive Secretary and members of the project office. Figure 1 shows an example of a possible corporate project office structure (8). 
The organizational structure of the project office should reflect the network nature of its organization. Interaction between groups takes place on the basis of horizontal links, without any administrative and managerial barriers, information and documents on projects should move freely from group to group in the forward and, if necessary, adjustments, in the opposite direction. The groups are not separate from each other, they work in different directions, but in close relationship with each other and in the interests of the project. To do this, it is necessary to carefully work out the methodological support for the activities of the project office. It is necessary not only to define a simple and understandable procedure for interaction of expert groups, but also to provide a free information space for their unhindered interaction with each other (Persod, 2014).

\section{Conclusion}

What is the average project failure rate? What factors have the greatest impact on the outcome of successful projects?

- The effectiveness of the project is growing all over the world. In 2019, almost 70\% of projects achieved their original goals or business intentions, while almost $60 \%$ of projects were completed within the initial budget. (PMI)

- $\quad$ IT projects are notoriously difficult to manage. A survey published in the Harvard Business Review found that the average IT project exceeded its budget by $27 \%$. Moreover, almost one in six it project turns into a "black Swan" (unexpected result has significant implications) with the overrun of $200 \%$ and an overrun of $70 \%$. (HBR)

Poor training of project managers, attempts to implement too many projects and lack of funding are the three main problems of project management in the Wellington survey. (Wellingtone)

Among IT projects, the failure rate largely corresponds to the size of the project. An IT project with a budget of more than $\$ 1$ million is 50\% more likely than a project with a budget of less than $\$ 350,000$. For such large IT projects, problems with functionality and exceeding deadlines are the two main causes of failures (22\% and $28 \%$, respectively). (Gartner)

A study conducted by $\mathrm{PwC}$ on 10,640 projects showed that only $2.5 \%$ of companies successfully complete their projects at $100 \%$. The rest either failed to meet their original goals or failed to meet their original budget or deadlines. These failures lead to significant costs - failed IT projects alone cost the United States \$ 50-150 billion in lost revenue and productivity. (Gallup)

- $\quad$ Among it projects, the effectiveness of the project varies considerably. While the average cost of software projects is $66 \%$, the same figure for non-software projects is $43 \%$. However, $133 \%$ of non-software projects do not meet the stated benefits, compared to $17 \%$ for software projects. (McKinsey) the company. (McKinsey)

$17 \%$ of IT projects can go so badly that they can endanger the very existence of

The list of groups included in the project office is formed in accordance with the strategic goals and directions. In the process of functioning of the project office, if necessary, new groups can be created in its structure. The project office is a living mobile structure designed to adapt to new conditions as mobile as possible.

A special place in the structure of the project office is occupied by the final expert assessment group (hereinafter referred to as the expert group). The task of the expert group is to assess the degree of elaboration of the project and its readiness to include the project in a comprehensive medium-term program. At the end of the evaluation process, the expert group forms an opinion on the inclusion of the project in the comprehensive development program, or, if necessary, sends the project for revision. 


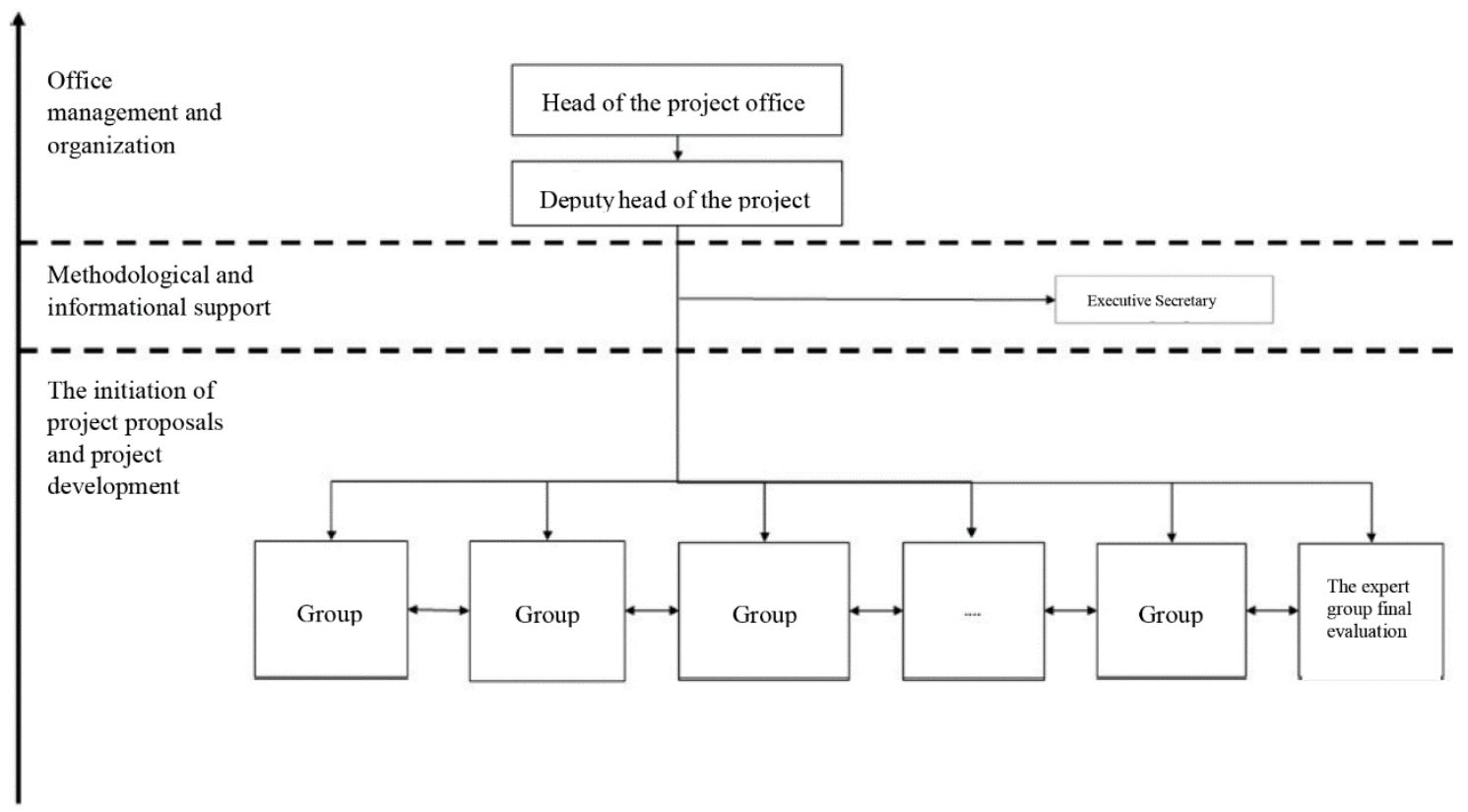

Fig. 1.Organizational structure of the project office in the corporation

When organizing a project office (committee), there are no universal approaches and methods. The structure, composition, and organization of the project office-all this depends on the specifics of the corporation itself, the level of maturity of the project management system, its organizational structure, scale, style, and methods of corporate governance. In this regard, the task of the authors is to describe the project approach as a tool for forming a comprehensive development program, however, each corporation needs to adapt this tool to its tasks and features (Gnedykh, 2015).

Below we present several mandatory components of preliminary work on the creation of a project office, which can improve the effectiveness of this tool:

- analysis of the business model, organization of business processes of the corporation, including analysis of current project activities and project management systems;

- development of the structure and concept of the project office (committee), which on the one hand corresponds to the development strategy of the corporation, and on the other hand corresponds to the organizational structure of the corporation;

- definition of project management standards and methodologies that are applicable to a particular corporation and allow the most effective organization of project activities;

- planning the organization of the project office (committee) as part of one of the corporation's projects (calculate the amount of work, necessary resources, determine stages, etc.) -

- formation of the project team in accordance with strategic goals, search for third-party consultants and experts;

- training the project team in the basics of project management. Such preparation for the organization of the project office will allow you to prepare the company and most effectively and painlessly implement project activities in order to form measures for the implementation of the strategy (Gnedykh, 2015).

Summing up, we emphasize that at present the project approach is the most progressive method of implementing the strategy in Russian and foreign companies. It allows you to work effectively, continuously and, most importantly, comprehensively on the formation of measures aimed at the long-term sustainable development of the company. The formation of a comprehensive development program for the medium-term period based on the project approach makes it possible to more clearly orient the current activities of the corporation to achieve its strategic goals. That is why, in the opinion of the authors, the project approach is the very tool that will allow the corporation to move to the desired level of development today.

\section{References}


Decree of the Government of the Russian Federation" On the organization of project activities in the Government of the Russian Federation " dated 15.10.2016 No. 1050. (Electronic resource) / Legal server "Consultant Plus". - Access mode: base.consultant.ru

Federal Law" On strategic Planning in the Russian Federation " of 28.06.2014 No. 172-FZ. (Electronic resource) / Legal server "Consultant Plus". - Mode of access: base. consultant.ru

Gnedykh,V.A. (2015). Features of the organization of the project office in the company.Young scientist, 5,576- 581 .

Kazmina, A.S.,\&Kotov,A.I. (2019). Using the project approach to form a mechanism for implementing the corporation's development strategy. Foresight " Russia»: the future of technology, economy and human beings. Volume 3 / Collection of reports of the V St. Petersburg International Economic Congress (SPEC-2019) / Under the general editorship of S. D. Bodrunov. St. Petersburg: INIR.

Magdanov, P. V. (2014). System of strategic planning in corporations. Vestnik of Perm University in, $1,77-89$

Nalchatji,T.A.,\&Malomatova, L.A. (2015). Strategic approach to industrial enterprise management. Scientific Almanac, 10-1, 293-296

Organization of the project management office (Electronic resource). Access mode: http://www.projectimo.ru

Persod,N.L. (2014). Project Office as a Communications Management Center. Management today, 240-255.

Project office (Electronic resource). Access mode: http: //forpm.ru.- (Accessed 01.03.2018).

Regulations on the project office "Smart St. Petersburg" dated 26.06.2017 approved by the Governor of St. Petersburg (Electronic resource). Access mode: http/ / wwwpetersburgsmartcity. ru- (Accessed: 20.02.2018).

Titov,S.A.,\&Novikova, N.A. (2014). Project office as an element of the corporate project management system: analysis and classification. Bulletin of the University, 14, 251-258.

Vaisblat,B.I., Sysoeva, A.A. (2009). Project office: optimization of project formation. Economic analysis: theory and practice, 26, p. 6-7.

Valiev, M. Sh. (2011). Project office as a promising management tool. Bulletin of VSGUTU, 2,8386. 